\title{
Survival and growth of three endangered oak species in a Mexican montane cloud forest
}

\author{
O.A. Valdés-Rodríguez, Y. García-De La Cruz, B.R. Frey
}

Valdés-Rodríguez O.A., García-De La Cruz Y., Frey B.R., 2017. Survival and growth of three endangered oak species in a Mexican montane cloud forest. Ann. For. Res. 60(1): 89-100.

Abstract. Cloud forests are amongst the world's most impacted and endangered forest types, with Mexican cloud forests amongst the most degraded. These species rich forests are characterized by a diversity of congeneric oak species which dominate the canopy of mature forests. An improved understanding of the establishment requirements of oak seedlings in cloud forests is needed for conservation and restoration purposes. The aim of this study was to assess the influence of light conditions during early establishment of three endangered Quercus species. Seedling growth and biomass allocation in Quercus insignis M. Martens \& Galeotti, Q. sartorii Liebm. and $Q$. xalapensis Bonpl. was determined under two light levels: light gap (1338 $\left.\mu \mathrm{mol} \mathrm{m} \mathrm{m}^{-2} \mathrm{~s}^{-1}\right)$ and closed canopy $\left(118 \mu \mathrm{mol} \mathrm{m} \mathrm{m}^{-2} \mathrm{~s}^{-1}\right)$ in a cloud forest in Veracruz, Mexico. Growth and development were evaluated over the first 13 months. Results suggest there was a significant effect of light conditions on growth rate and biomass allocation. Although survival rate was similar among both environments, the three species showed lower growth rates under the closed canopy during the first nine months, while elongation rate was higher during the last three months under this environment compared to the light gap. Across all species, fresh biomass and dry biomass of roots, stem and leaves were almost 50\% higher in light gap than under closed canopy. $Q$. insignis produced more biomass in shoots and roots than $Q$. sartorii and $Q$. xalapensis, which may increase its establishment success in shaded conditions. Results suggest that these three oak species are suited to planting in small gaps, but also in shaded understory conditions, as high early survival $(>90 \%)$ may allow enrichment planting in advance of gap creation. Keywords regeneration, seedlings, light gap, closed canopy

Authors. Ofelia Andrea Valdés-Rodríguez - El Colegio de Veracruz, Carrillo Puerto no. 26, CP 91000, Xalapa Veracruz, Mexico; Yureli García-De La Cruz (yugarcia@uv.mx) - Centro de Investigaciones Tropicales, Universidad Veracruzana, José María Morelos 44, CP 91000, Xalapa, Veracruz, Mexico; Brent R. Frey - Department of Forestry, Mississippi State University. 775 Stone Boulevard, Mississippi State, Mississippi, United States, 39762.

Manuscript received August 22, 2016; revised January 31, 2017; accepted February 4, 2016; online first February 09, 2017. 


\section{Introduction}

Globally, tropical montane cloud forests represent unique and diverse forest types, and are considered the world's most impacted and endangered forest types but also the least studied (Bubb et al. 2004). Mexican cloud forests are biologically diverse, yet also amongst the most threatened forest types in the world (Williams-Linera 2007). While recognized for their species-richness, they have been reduced in extent through deforestation, fragmentation, and degradation, with cloud forests in the eastern region of Mexico exhibiting a 90\% loss (Williams-Linera 2007). Subsistence agriculture, fuelwood/timber harvesting, and expansion of commercial agricultural activities (predominantly cattle ranching and coffee plantations) have been the primary drivers of forest loss (Williams-Linera et al. 2002).

As a consequence, key components have become threatened, including a diversity of Quercus species which characterize the cloud forests of eastern Mexico. Several oak species are important large canopy dominants of these forest types, yet today they are often poorly represented in smaller size classes raising concerns about regeneration limitations (Alfonso-Corrado et al. 2014). While a number of studies have evaluated regeneration characteristics of Mexican cloud forest tree species (Figueroa-Rangel \& Olvera-Vargas 2000, Ramírez-Bamonde et al. 2005), few have directly compared germination and early establishment across multiple oak species (López-Barrera et al. 2006). Tree regeneration processes are affected by biotic and abiotic factors, which determine the success of the species. Among them, seedling establishment is considered the most vulnerable stage because new individuals have to be capable of developing sufficient photosynthetic tissues and structural support to survive under stressful and competitive conditions (Fenner \& Thompson 2005, Kitajima \& Fenner 2000, Leck \& Outred 2008). The study of growth characteristics, such as growth rates, biomass production and biomass allocation under different environments can provide insights into the ontogeny of the species and their environmental adaptations and habitat associations (Poorte \& Nagel 2000). For example, plant growth analysis is useful for interpreting plant function (Hunt et al. 2002), as structural development, particularly canopy (leaf area) dynamics, and biomass allocation patterns, define plant's ability to compete with other species (Givnish 1988). In this regard, light and nutrients play important roles in biomass production and allocation patterns (Poorte \& Nagel 2000).

In tropical rainforests, light is one of the most important factors that affect establishment, growth and survival of seedling (Poorter 2001). Plant light requirements depend not only on shade tolerance but also on growth stage, and can change, as individuals transition from seedling to sapling, to canopy dominant (Augspurger 1984). During seedling development, trees growing under the shade of a canopy will receive a limited amount of light, which might decrease their survival rates, but allocational responses, such as an increase in specific leaf area, may allow for persistence in conditions that are less than optimal (e.g. low light, high competition; Augspurger 1984). Therefore, partial shelter may provide a suitable environment for some trees to survive where competition may be less severe than in more open disturbed areas.

The response of some species of the genus Quercus to light of different intensities indicates that they are characterized by a high degree of photosynthetic plasticity and adaptations to different micro-environmental conditions, which are expressed through different rates of photosynthesis and stomatal conductance, leaf anatomy and Rubisco activity (Valladares et al. 2002, Ashton \& Berlyn 1994). Nonetheless, little is known about many neotropical oak species, including the species Quercus insignis M. Martens \& Galeotti, Q. xalapensis Bonpl. and Q. sartorii Liebm., all native species of American tropical 
mountain cloud forests (González-Espinosa et al. 2011). These species are considered important canopy dominants of Mexican cloud forests; however, there is limited information about their regeneration ecology, growth and suitable environments for their establishment (González-Espinosa et al. 2011, Ramírez-Bamonde et al. 2005). Conservation of these endangered oak species is essential due to increasing loss of montane cloud forest to agriculture and development. These species have local importance as fuel wood, construction materials, and in handicrafts (Benitez Badillo et al. 2004), while many other uses remain unexplored. An increased understanding of seedling establishment, particularly in relation to light conditions, will better inform silvicultural and restorational approaches aimed at maintaining the integrity of tropical montane cloud forests. The objective of this study was to evaluate the effects of light availability on growth and biomass allocation in seedlings of Quercus insignis, Q. sartorii and Q. xalapensis in closed canopy and light gap conditions in a cloud forest.

\section{Material and methods}

\section{Study site}

This study was established in a remnant of a tropical mountain cloud forest located in the municipality of Coatepec, central region of Veracruz (east of Mexico; $19^{\circ} 27^{\prime}$ '59.7' $\mathrm{N}$ and $\left.96^{\circ} 57^{\prime} 09.1^{\prime} \mathrm{W}\right), 1250 \mathrm{~m}$ asl (Figure 1). The study area was located in a secondary forest that was 15 years old, having developed on former cloud forest land that had been cleared for coffee plantations and then subsequently abandoned. The climate is considered semi warm humid tropical (A)C (fm) (Köppen modified by García 1973), with an average temperature of $22^{\circ} \mathrm{C}$ in the warmest month, and $18^{\circ} \mathrm{C}$ in the coldest month. Soils are classified as andisols, dark brown to black color, silty-textured, with a depth of 30 to $60 \mathrm{~cm}$ (Castillo \& Luna 2009). The topography is characterized by steep slopes and narrow ridges.

Two different micro sites were selected for sowing and growing the seedlings: 1) a closed canopy forest stand composed of native trees (Clethra mexicana A. DC., Persea shiedeana Nees., Platanus mexicana Moric., Q. lancifolia Schltdl. \& Cham, Trema micrantha L. with tree average basal area of $0.16 \mathrm{~m}^{2}$ ), and 2) a treefall light gap size of $400 \mathrm{~m}^{2}$ (hereafter referred to as 'light gap'). Climate conditions were recorded from each micro site. The photosynthetically active radiation (PAR) was measured every hour between 9:00 am until 4:00 pm, during every day of the sampling period, using a linear ceptometer (AccuPAR LP80 Decagon $\AA$, resolution $\left.1 \mu \mathrm{mol} \mathrm{m} \mathrm{m}^{-2} \mathrm{~s}^{-1}\right)$. Average temperature and relative humidity were estimated on a daily basis using an Onset Data Logger with temperature and humidity sensors (HOBO Pro Series H08-032-08). Site conditions are presented in Table 1.

\section{Seed material and seedling production}

From each species 600 acorns were collected beneath ten trees in a cloud forest fragment in central Veracruz $\left(19^{\circ} 33^{\prime} 20.30^{\prime \prime} \mathrm{N}\right.$ and $\left.96^{\circ} 56^{\prime} 37.85^{\prime} \mathrm{W}\right)$. Healthy acorns were selected by the float method (Gribko and Jones, 1995), weighed, and then immediate-

Table 1 Values of the abiotic variables registered under a light gap and closed canopy during a period of 13 months (average \pm S.E.)

\begin{tabular}{lllll}
\hline Site & PAR $\left(\mu \mathrm{mol} \mathrm{m} \mathrm{s}^{-1}\right)$ & $\begin{array}{l}\text { Percentage of } \\
\text { total light }\end{array}$ & $\begin{array}{l}\text { Temperature } \\
\left({ }^{\circ} \mathrm{C}\right)\end{array}$ & $\begin{array}{l}\text { Relative } \\
\text { humidity }(\%)\end{array}$ \\
\hline Light gap & $1337.60 \pm 216.19$ & 100 & $17.92 \pm 0.81$ & $84.85 \pm 4.76$ \\
\hline Closed canopy & $117.47 \pm 28.37$ & 8.78 & $17.06 \pm 0.77$ & $89.74 \pm 0.75$ \\
\hline
\end{tabular}


ly sown into polyethylene bags (20 $\mathrm{cm}$ wide by $20 \mathrm{~cm}$ deep). The bags were filled with soil from the forest mixed 50:50 with lava rocks to facilitate aeration. A total of 120 bags with five acorns per bag were placed inside a greenhouse under a transparent plastic cover located in the light gap. Once germination (defined as the emergence of the radicle and hypocotyledon) occurred, each germinant was transplanted to a single polyethylene bag $(20 \times 20$ $\mathrm{cm}$ ) and grown for one month before being randomly assigned to its corresponding environment.

\section{Experimental design}

One month after their emergence, eighty seedlings of uniform size per species were selected (i.e. exceedingly large or small individuals were not included). Forty seedlings of each species were placed in the light gap, and forty seedlings were located in the closed-canopy. Bags were placed on the ground and rotated weekly within the light treatment and watered as needed to maintain soil moisture conditions. A

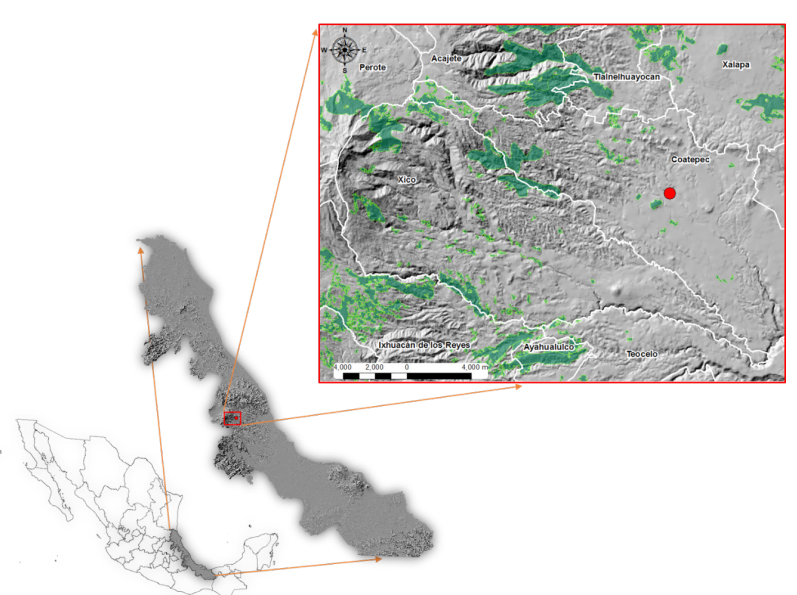

Figure 1 Study site. The gray areas represent the state of Veracruz, Mexico. The green areas represent the fragmented distribution of the cloud forests in the zone. The red dot indicates the location of the study area. Map information provided by the National Forest Commission (SEMARNAT 2013).

total of 240 seedlings were monitored at the third, sixth, ninth and thirteenth month from the beginning of the experiment. Survival, plant height (to $1 \mathrm{~mm}$ ) and root collar diameter (RCD; digital Vernier, precision $0.01 \mathrm{~mm}$ ) were measured at each sampling interval.

\section{Destructive sampling}
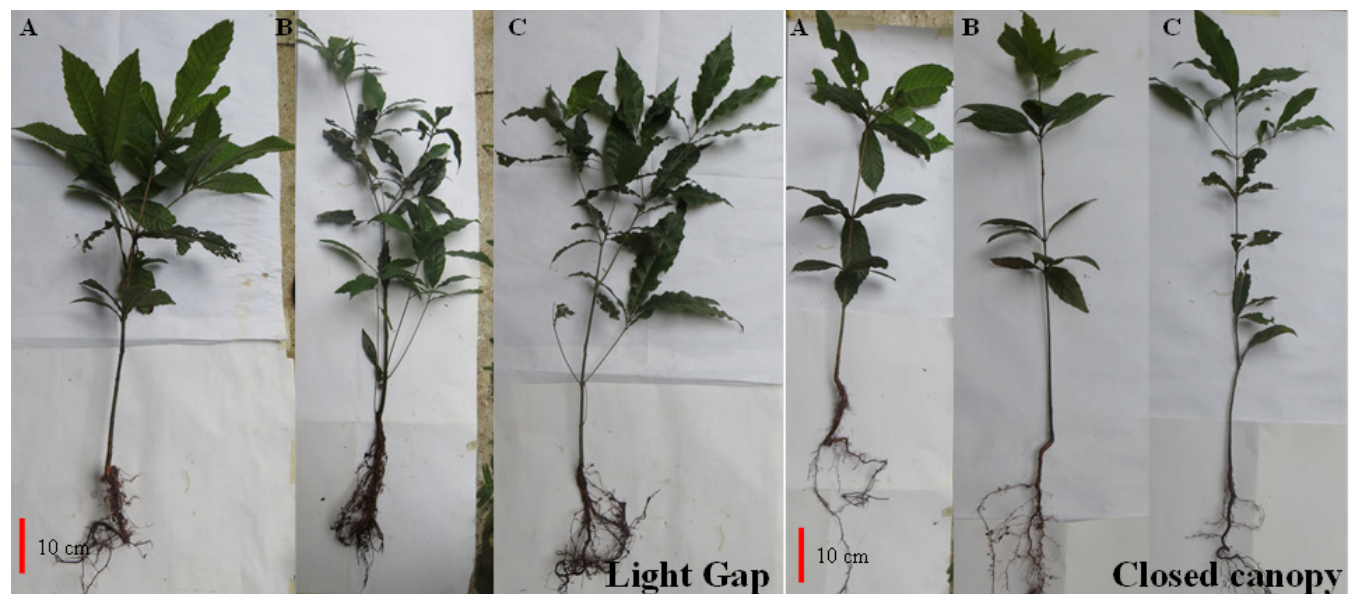

Figure 2 Representative images of 13 month old seedlings of A) Q. insignis, B) Q. sartorii and C) Q. xalapensis grown within light gap and a closed canopy conditions 
After thirteen months, 10 seedlings of each species in each light regime (60 seedlings total) were randomly selected for destructive sampling to assess biomass allocation. Each individual seedling was removed from its polyethylene bag and its roots washed off to remove any loose soil (Figure 2). The roots were gently blotted with soft paper towel to remove any free surface moisture, and each plant was separated into leaf, stem and roots to determine fresh weight of each component. The fresh weight was determined with an analytic scale (accuracy $0.01 \mathrm{~g}$ ). Leaf area $\left(\mathrm{cm}^{2}\right)$ was estimated by scanning each leaf, and analyzing the images using Image J (v.1.48) and image analysis software (Rasband ImageJ $($ )). Additionally, length and diameter of the principal and secondary roots were measured with a measuring tape $(1.0 \mathrm{~mm}$ resolution) and all the secondary roots were counted (roots emerging from the tap root with diameter greater than $1.0 \mathrm{~mm}$ ). Subsequently, plant components were oven dried for 48 hours at $80^{\circ} \mathrm{C}$ (drying oven Yamato model DX 602), then dry weight and water content were obtained. Leaf area ratio (LAR - relation of leaf area and dry weight, $\mathrm{cm}^{2} \cdot \mathrm{g}^{-1}$ ), leaf mass fraction (LMF - relation of leaf biomass and total biomass, $\mathrm{g} \cdot \mathrm{g}^{-1}$ ), stem mass fraction (SMF - relation of stem biomass and total biomass, $\left.\mathrm{g} \cdot \mathrm{g}^{-1}\right)$ and root mass fraction (RMF - relation of root biomass and total biomass, $\left.g \cdot g^{-1}\right)$ were estimated.

\section{Data analyses}

At the end of the experimental period a survival analysis was performed using the Kaplan-Meier method implemented in SPSS (v. 19). The Kaplan-Meier survival analysis was used because it can account for right-censored data (in this case, seedlings which remain alive at the end of the sampling period). Survival probabilities were assessed at three month intervals and a final four month interval $(3,6,9$, 13 months). The experiment was run for an additional month to assess growth over a second winter season, since this a critical period of the year to evaluate survival capabilities. While this meant that the final time interval was longer, the assumption of survival rate uniformity still applies to each time period, along with the other Kaplan-Meier assumptions (including independence of censoring and the event, and sufficient sample sizes). Differences in seedling survival were tested between species and light environments using the Log Rank test. All tests were evaluated at a level of significance of $\alpha=0.05$.

Normality and equal variance tests were conducted and, variables that met the normality and variance assumptions were analyzed with two way ANOVAs. For variables that were not normal (RMF, leaf number, leaf area and water content in stem), we used Generalized Linear Models (GLMs) with a log link function to evaluate differences among treatments. Tests were performed using $\mathrm{R}$ studio environment (v 1.0.44). All tests were evaluated at a level of significance of $\alpha=0.05$.

Additionally, the growth curves of the stem (RCD and height) among species and environments were compared with the help of a Richard's generalized logistic model (Colbert et al. 2003) defined by Eq. (1), where $v(t)$ is the height or RCD at a " $t$ " time, Vmax is the average (height or RCD) of the dominant species (the dominant species being the one with the highest average value), $K$ is a constant of the curve, $a$ is a constant of growth rate and $t$ is the period of time after emergence. The logistic model was chosen because it is well-suited to the early growth of a germinating seedling, from emergence to rapid initial growth to slowing as the seed reserves are exhausted and the plant must exist on external resources. To determine growth rate and curve parameters we developed an algorithm in LabView 12.0. For each estimated model (Table 2), a goodness of fit was obtained by using the adjusted coefficient of determination for multiple regressions defined by Zar (1999).

$v(t)=\frac{V \max }{1+k * e^{-a t}}$ 


\section{Results}

\section{Survival, plant size and morphology}

Seedling survival trends were not different between species $(p=0.53)$ and light environments $(p=0.16)$. Final survival was similar between species $(p=0.06 ; Q$. sartorii $=91.25$ $\pm 3.17 \%$, Q. insignis $=90.0 \pm 3.37 \%$, Q. xalapensis $=80.0 \pm 4.50 \%$ ).

At the end of the experimental period the relationship height/RCD (slenderness) differed between environment and species $(p=0.014$, Table 3). Q. insignis and Q. sartorii registered higher values within the light gap than under closed canopy. The slenderness in Q. xalapensis was not statistically different between light conditions $(p=0.2)$.

Above- and below-ground development was different between species and environments (Table 3, Figure 3). The effects of light conditions were observed in plant height, RCD, number of leaves and leaf area, which were higher in the gap environment. LAR had not a statistically significant interaction between species and environment $(p=0.35)$, except for $Q$. sartorii, which had higher LAR in the closed canopy. Comparing between species, Q. insignis had the highest RCD and leaf area, while $Q$. sartorii produced higher number of leaves than $Q$. xalapensis and $Q$. insignis.

\section{Biomass allocation}

Fresh biomass and dry biomass were different between species and environments $(P<$ $0.0001)$. Fresh and dry weights were $50 \%$ higher under light gap conditions for the three species, being highest in $Q$. insignis which produced $65 \%$ more biomass in leaves, $48 \%$ more in stem and $60 \%$ more in roots than $Q$. sartorii and Q. xalapensis. Water content was similar between environments, except for $Q$. insignis, which had the highest water content in its roots in the closed canopy. For the three species LMF and SMF were similar in both en- vironments; although among them, $Q$. insignis registered the lowest SMF, while $Q$. sartorii and $Q$. xalapensis registered the lowest $\mathrm{RMF}$ under closed canopy.

\section{Growth patterns}

Q. insignis was the only species with similar height growth rate under both environments $(p=0.1)$, and it had higher RCD growth rate under light gap compared to $Q$. sartorii and $Q$. xalapensis $(p<0.001)$. Q. sartorii and $Q$. xalapensis registered lower growth rates (height and RCD) under the light gap, with significant lower rates in the shaded environment $(p<$ 0.001). (Figure 3, Table 2).

\section{Discussion}

\section{Survival and growth rate}

The high survival in both environments suggests tolerance of the three species to closed canopy and gap environments. The average $65 \%$ reduction in height growth and $32 \%$ in RCD growth during the first nine months under the closed canopy is consistent with reported growth reductions in Quercus in other regions. For example, Q. rubra, from the eastern United States and southeastern Canada, registered 30 $\%$ higher growth in higher vs. lower light conditions (510-580 vs $180-210 \mu \mathrm{mol} \mathrm{m} \mathrm{m}^{-2} \mathrm{~s}^{-1}$; Van Hees 1997); and Q. pagoda seedlings, from the southern United States, were $146 \%$ taller in intermediate light levels (53\% and $27 \%$ of full sunlight) compared with low understory light levels of 8\% (Gardiner \& Hodges 1998). However, in our experiment it should be noted that, while during the first nine months elongation and RCD growth rates were lower in the shaded environment; by the thirteenth month shoot elongation was higher under lower light conditions. This suggests that these Quercus were showing a phenotypic adaptation to the environment (Poorte \& Nagel 2000). 
Table 2 Parameters estimated for the adjusted growth curves of the three Quercus species based on height and root collar diameter in two different environments: a) light gap and b) closed canopy

\begin{tabular}{|c|c|c|c|c|c|c|c|c|c|}
\hline \multirow[b]{2}{*}{ Species } & \multirow[b]{2}{*}{$\begin{array}{l}\text { Environ- } \\
\text { ment }\end{array}$} & \multicolumn{4}{|l|}{ Height } & \multicolumn{4}{|c|}{ Root Collar Diameter } \\
\hline & & $V_{\max }(\mathrm{cm})$ & $K$ & $\begin{array}{l}\alpha \text { (growth } \\
\text { rate) }\end{array}$ & $R^{2}$ & $V_{\max }(\mathrm{cm})$ & $K$ & $\begin{array}{l}\alpha \text { (growth } \\
\text { rate) }\end{array}$ & $R^{2}$ \\
\hline \multirow[b]{2}{*}{ Q. insignis } & light gap & 84.24 & 6.28 & $1.38 \times 10^{-02}$ & 0.92 & 11.13 & 4.00 & $1.10 \times 10^{-02}$ & 0.93 \\
\hline & $\begin{array}{l}\text { closed } \\
\text { canopy }\end{array}$ & 47.1 & 1.62 & $8.10 \times 10^{-03}$ & 0.98 & 8.83 & 2.70 & $1.05 \times 10^{-02}$ & 0.95 \\
\hline \multirow[b]{2}{*}{ Q. sartorii } & light gap & 84.24 & 6.28 & $1.04 \times 10^{-02}$ & 0.96 & 11.12 & 4.00 & $6.00 \times 10^{-03}$ & 0.97 \\
\hline & $\begin{array}{l}\text { closed } \\
\text { canopy }\end{array}$ & 47.1 & 1.62 & $5.20 \times 10^{-03}$ & 0.84 & 8.83 & 3.51 & $4.10 \times 10^{-03}$ & 0.71 \\
\hline \multirow{2}{*}{$\begin{array}{l}Q . \\
\text { xalapensis }\end{array}$} & light gap & 84.24 & 6.28 & $9.60 \times 10^{-03}$ & 0.97 & 11.12 & 4.00 & $7.10 \times 10^{-03}$ & 0.92 \\
\hline & $\begin{array}{l}\text { closed } \\
\text { canopy }\end{array}$ & 47.1 & 1.62 & $7.10 \times 10^{-03}$ & 0.96 & 8.83 & 2.65 & $2.90 \times 10^{-03}$ & 0.76 \\
\hline
\end{tabular}

Table 3 Above and below ground parameters and biomass allocation in 13 month old seedlings of three Quercus species grown under different light conditions (light gap and closed canopy). Values are expressed as means \pm S.E. Different lower case letters represent significant differences between environments. Different uppercase letters represent significant differences between species.

\begin{tabular}{|c|c|c|c|c|c|c|c|c|}
\hline \multirow{2}{*}{ Parameter } & \multicolumn{8}{|c|}{ Species } \\
\hline & \multicolumn{2}{|l|}{ Q. insignis } & \multicolumn{3}{|l|}{ Q. sartorii } & \multicolumn{3}{|l|}{ Q. xalapensis } \\
\hline \multirow[t]{2}{*}{ Seed weight (g) } & \multicolumn{2}{|l|}{$34.68 \pm 0.43 \mathrm{~A}$} & \multicolumn{3}{|l|}{$3.05 \pm 0.02 \mathrm{~B}$} & \multicolumn{3}{|l|}{$2.77 \pm 0.03 \mathrm{C}$} \\
\hline & Light Gap & Closed Canopy & Light Gap & \multicolumn{2}{|l|}{ Closed Canopy } & Light Gap & \multicolumn{2}{|l|}{ Closed Canopy } \\
\hline \multicolumn{9}{|c|}{ a) Aboveground parameters } \\
\hline Survival rate (\%) & $85.0 \pm 5.7^{\mathrm{a}}$ & $95.0 \pm 3.4^{\mathrm{a}}$ & A $87.5 \pm 5.2^{\mathrm{a}}$ & $95 \pm 3.4^{\mathrm{a}}$ & A & $70.0 \pm 7.3^{b}$ & $90.0 \pm 4.8^{\mathrm{a}}$ & A \\
\hline Height (cm) & $84.23 \pm 3.86^{\mathrm{a}}$ & $47.10 \pm 2.37^{\mathrm{b}}$ & A $77.79 \pm 3.01^{\mathrm{a}}$ & $40.44 \pm 1.42^{b}$ & A & $74.75 \pm 3.50^{\mathrm{a}}$ & $36.44 \pm 1.73^{\mathrm{b}}$ & A \\
\hline $\mathrm{RCD}(\mathrm{mm})$ & $8.46 \pm 1.70^{\mathrm{a}}$ & $6.72 \pm 1.67^{\mathrm{b}}$ & A $7.82 \pm 2.48^{\mathrm{a}}$ & $3.97 \pm 0.91^{\mathrm{b}}$ & $\mathrm{B}$ & $6.23 \pm 1.71^{\mathrm{a}}$ & $3.80 \pm 1.00^{\mathrm{b}}$ & $\mathrm{B}$ \\
\hline Slenderness & $7.78 \pm 0.32^{\mathrm{a}}$ & $5.46 \pm 0.24^{\mathrm{b}}$ & B $9.70 \pm 0.61^{\mathrm{a}}$ & $7.61 \pm 0.26^{\mathrm{b}}$ & A & $8.53 \pm 0.52^{\mathrm{a}}$ & $7.64 \pm 0.40^{\mathrm{a}}$ & A \\
\hline Number of leaves & $27.2 \pm 8.6^{\mathrm{a}}$ & $15.3 \pm 6.46^{b}$ & B $43.2 \pm 29.13^{\mathrm{a}}$ & $17.8 \pm 9.69^{b}$ & A & $28.8 \pm 12.63^{\mathrm{a}}$ & $11.1 \pm 6.92^{\mathrm{b}}$ & B \\
\hline Branches & $2.1 \pm 0.99^{\mathrm{a}}$ & $2.1 \pm 1.1^{\mathrm{a}}$ & A $2.4 \pm 1.35^{\mathrm{a}}$ & $1.3 \pm 0.48^{\mathrm{b}}$ & A & $2 \pm 0.47^{\mathrm{a}}$ & $1.6 \pm 0.84^{\mathrm{a}}$ & A \\
\hline Leaf area $\left(\mathrm{cm}^{2}\right)$ & $1436.3 \pm 671.7^{\mathrm{a}}$ & $735.9 \pm 449.7^{b}$ & A $693.5 \pm 464.4^{\mathrm{a}}$ & $220.0 \pm 195.3^{\mathrm{b}}$ & $\mathrm{B}$ & $422.2 \pm 244.3^{\mathrm{a}}$ & $136.0 \pm 100.3^{\mathrm{b}}$ & $\mathrm{C}$ \\
\hline $\operatorname{LAR}\left(\mathrm{cm}^{2} \mathrm{~g}_{-}{ }^{1}\right)$ & $53.68 \pm 8.12^{\mathrm{a}}$ & $62.659 \pm 6.73^{\mathrm{a}}$ & A $42.963 \pm 4.87^{\mathrm{b}}$ & $63.748 \pm 6.81^{\mathrm{a}}$ & A & $47.903 \pm 4.61^{\mathrm{a}}$ & $50.689 \pm 5.72^{\mathrm{a}}$ & A \\
\hline \multicolumn{9}{|c|}{ b) Belowground parameters } \\
\hline $\begin{array}{l}\text { Tap root length } \\
(\mathrm{cm})\end{array}$ & $50.46 \pm 16.2^{\mathrm{a}}$ & $41.36 \pm 12.96^{\mathrm{a}}$ & A $47.27 \pm 13.34^{\mathrm{a}}$ & $34.04 \pm 11.2^{\mathrm{b}}$ & A & $50 \pm 12.37^{\mathrm{a}}$ & $33.83 \pm 6.26^{\mathrm{b}}$ & A \\
\hline $\begin{array}{l}\text { Root collar } \\
\text { diameter }(\mathrm{mm})\end{array}$ & $11.07 \pm 2.35^{\mathrm{a}}$ & $9.63 \pm 2.67^{\mathrm{a}}$ & A $9.07 \pm 2.99^{\mathrm{a}}$ & $4.6 \pm 0.99^{b}$ & $\mathrm{~B}$ & $6.92 \pm 1.88^{\mathrm{a}}$ & $4.28 \pm 0.9^{b}$ & B \\
\hline $\begin{array}{l}\text { Tip of tap root } \\
(\mathrm{mm})\end{array}$ & $0.38 \pm 0.19^{\mathrm{a}}$ & $0.53 \pm 0.35^{\mathrm{a}}$ & A $0.30 \pm 0.12^{\mathrm{a}}$ & $0.32 \pm 0.19^{\mathrm{a}}$ & A & $0.43 \pm 0.16^{\mathrm{a}}$ & $0.38 \pm 0.18^{\mathrm{a}}$ & A \\
\hline $\begin{array}{l}\text { Number of lateral } \\
\text { roots up to } 10 \mathrm{~cm}\end{array}$ & $53.2 \pm 44^{\mathrm{a}}$ & $61.5 \pm 30.6^{\mathrm{a}}$ & A $48.5 \pm 25.37^{\mathrm{a}}$ & $28.4 \pm 18.18^{a}$ & A & $36.2 \pm 19.03^{\mathrm{a}}$ & $36.7 \pm 14.35^{\mathrm{a}}$ & A \\
\hline $\begin{array}{l}\text { Number of lateral } \\
\text { roots below } 10 \\
\mathrm{~cm}\end{array}$ & $109.6 \pm 58.2^{\mathrm{a}}$ & $89.5 \pm 37.81^{\mathrm{a}}$ & A $113.4 \pm 53.63^{\mathrm{a}}$ & $43.3 \pm 12.6^{\mathrm{b}}$ & $\mathrm{AB}$ & $78.4 \pm 23.89^{\mathrm{a}}$ & $45 \pm 20.72^{b}$ & B \\
\hline $\begin{array}{l}\text { Lateral root } \\
\text { diameters }(\mathrm{mm})\end{array}$ & $0.32 \pm 0.13^{\mathrm{a}}$ & $0.26 \pm 0.1^{\mathrm{a}}$ & A $0.31 \pm 0.21^{\mathrm{a}}$ & $0.28 \pm 0.16^{\mathrm{a}}$ & A & $0.40 \pm 0.22^{\mathrm{a}}$ & $0.21 \pm 0.13^{\mathrm{b}}$ & A \\
\hline $\begin{array}{l}\text { Surface } \\
\text { projection }(\mathrm{cm})\end{array}$ & $20.00 \pm 1.45^{\mathrm{a}}$ & $14.80 \pm 1.42^{\mathrm{a}}$ & A $16.40 \pm 0.97^{\mathrm{a}}$ & $10.40 \pm 1.01^{\mathrm{b}}$ & A & $16.40 \pm 1.15^{\mathrm{a}}$ & $11.00 \pm 1.37^{\mathrm{b}}$ & A \\
\hline \multicolumn{9}{|c|}{ c) Biomass allocation } \\
\hline $\operatorname{LMF}\left(g \cdot g^{-1}\right)$ & $37.32 \pm 2.55^{\mathrm{a}}$ & $38.35 \pm 3.07^{\mathrm{a}}$ & A $29.29 \pm 2.54^{\mathrm{a}}$ & $35.85 \pm 4.14^{\mathrm{a}}$ & A & $30.86 \pm 3.11^{\mathrm{a}}$ & $34.78 \pm 3.85^{\mathrm{a}}$ & A \\
\hline $\operatorname{SMF}\left(g \cdot g^{-1}\right)$ & $25.19 \pm 2.12^{\mathrm{a}}$ & $25.67 \pm 0.93^{\mathrm{a}}$ & B $33.6 \pm 1.67^{\mathrm{a}}$ & $37.51 \pm 2.48^{\mathrm{a}}$ & A & $29.93 \pm 2.81^{\mathrm{a}}$ & $33.13 \pm 2.31^{\mathrm{a}}$ & A \\
\hline $\operatorname{RMF}\left(g \cdot g^{-1}\right)$ & $37.49 \pm 1.70^{\mathrm{a}}$ & $35.97 \pm 3.19^{\mathrm{a}}$ & A $37.04 \pm 3.60^{\mathrm{a}}$ & $26.64 \pm 2.49^{b}$ & $\mathrm{~B}$ & $39.21 \pm 4.26^{\mathrm{a}}$ & $32.08 \pm 2.23^{\mathrm{b}}$ & A \\
\hline
\end{tabular}



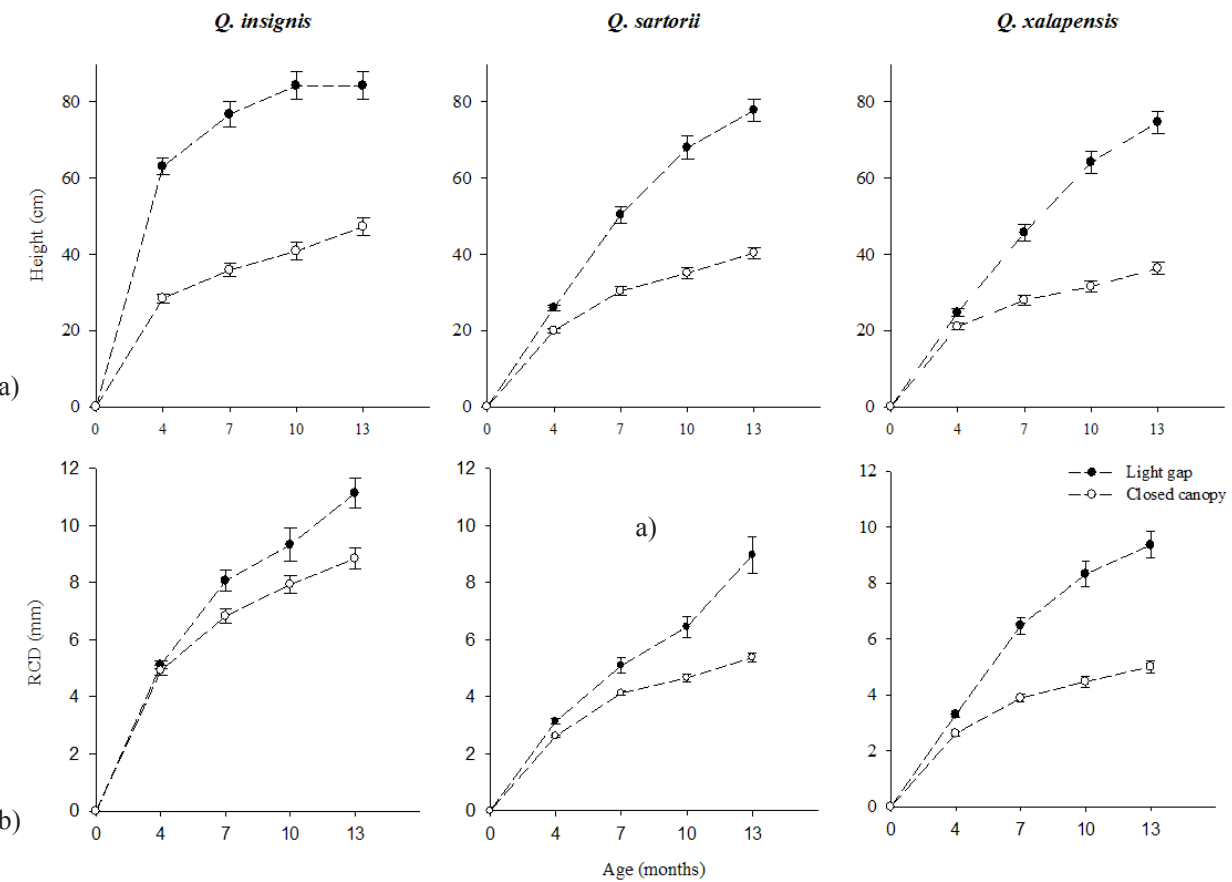

Figure 3 Average a) height and b) root collar diameter growth rates registered in three Quercus seedling species under two different environments: light gap and closed canopy during the experimental period

Research over the genus has found that there are Quercus spp. that might adopt different strategies at lower light levels. For example, the North American white oak $Q$. alba registered $32 \%$ higher growth under shaded canopies than under full sun (Dillaway et al. 2007). Likewise, the Mediterranean $Q$. ilex and $Q$. pyrenaica exhibited $25 \%$ and $23 \%$ higher growth respectively under $13 \%$ of total light $\left(180.2 \mu \mathrm{mol} \mathrm{m} \mathrm{m}^{-2} \mathrm{~s}^{-1}\right)$, than under $80 \%$ (1210 $\left.\mu \mathrm{mol} \mathrm{m} \mathrm{m}^{-2} \mathrm{~s}^{-1}\right)$ and full sunlight $\left(1513 \mu \mathrm{mol} \mathrm{m} \mathrm{m}^{-2}\right.$ $\mathrm{s}^{-1}$ ) (Gómez-Aparicio et al. 2006). Saplings of these oak species suffer photoinhibition that reduces their capacity to maximize photosynthesis at high light levels (Gómez-Aparicio et al. 2006).

Other cloud forest oaks, like Q. salicifolia, show a similar growth pattern to the ones studied here, since its growth is higher in levels of 55-60\% of full light (Saldaña-Acosta et al. 2009) compared with 3-20\% light availability.
Previous studies about $Q$. xalapensis reported lower growth and biomass production under closed canopy compared to open areas, although light availability data was not presented (De la Riva et al., 2014;Ramírez-Bamonde et al., 2005). In contrast Montes-Hernández \& López-Barrera (2013) found that seedlings of $Q$. insignis grew taller under partial shade (about $34.5 \%$ of full light) compared to growth in full light. These results suggest that Q. insignis might perform better under closed canopy and light gaps than under fully open areas, like grasslands.

Among the three species, Q. insignis, had the highest above ground growth rates in both environments during the first three months. It is likely that the larger acorn in $Q$. insignis provided greater reserves and allowed more rapid early growth, while the smaller acorns of $Q$. sartorii and $Q$. xalapensis likely provide lower reserves for early growth, as it has been docu- 
mented for other Quercus in America (Danner \& Knapp 2001).

\section{Plant size and morphology}

Considering the slow growth rates, plant size under closed canopy was about $50 \%$ of that under the light gap for the three species. However, morphological changes were observed only in $Q$. sartorii, which responded to the lower light regime by increasing its LAR index (Table 3), being 1.5 times higher than $Q$. insignis and 1.2 higher than Q. xalapensis. Similar behavior was found in $Q$. robur seedlings, a widespread species from Europe, which increased SLA and LAR with decreasing light availability (from 1536-1263 $\mu \mathrm{mol} \mathrm{m} \mathrm{m}^{-2} \mathrm{~s}^{-1}$ to 219-151 $\left.\mu \mathrm{mol} \mathrm{m} \mathrm{m}^{-2} \mathrm{~s}^{-1}\right)$ after a period of more than one year (Valladares et al. 2002).

The fact that $Q$ insignis had the largest size and still maintained a similar RCD, tap root and lateral roots development among different environments could be attributed to its larger acorn, which provided greater reserves (Welander \& Ottoson 1998). The larger acorn and lower slenderness (height $\cdot \mathrm{RCD}^{-1}$ ) in $Q$. insignis are characteristics of an intermediate successional species, while smaller acorns and higher slenderness, as in $Q$. sartorii and $Q$. xalapensis are common in early successional species, which can perform better in subsequent years (Tanouchi 1996).

\section{Biomass allocation}

Significant lower biomass production under shade in the three species is consistent with other cloud forests species, like Citharexylum mocinnii, Magnolia iltisiana, Fraxinus udhei and Dendropanax arboreus, which have lower biomass production under low light conditions (Saldaña-Acosta et al. 2009). Similar performance was reported in other Quercus species, such as $Q$. rubra, which allocates more biomass in the first year to leaves, stem and roots under $70 \%$ of full sunlight than at $9 \%$ of full sunlight (Welander \& Ottonson 1998). Q. gil- $v a$, from southwestern Japan, exhibits a low mortality rate under $2 \%$ of full sunlight, but greater growth under full sunlight conditions (Tanouchi 1996). Similar RMF, LMF and SMF among the different light regimes means that light conditions did not have a significant effect on biomass allocation in leaves stems and roots for $Q$. insignis and $Q$. xalapensis. However, root fraction was lower for $Q$. sartorii at lower light levels because the stem and leaves gained more biomass to improve its photosynthetic capacity, an indication of its higher phenotypical adaptation.

The higher biomass production in all the organs of $Q$. insignis compared with $Q$. sartorii and $Q$. xalapensis may be attributable to its larger acorns, which are approximately 11 times heavier than $Q$. sartorii and 13 times heavier than $Q$. xalapensis. As a consequence, during its early establishment, $Q$. insignis has a greater potential to develop under partial openings (small light gaps) or shaded conditions than the other two species, even after a period of more than one year. However, as earlier successional species, $Q$. sartorii and $Q$. xalapensis might grow faster than $Q$. insignis after longer periods of time beyond early establishment. Given the long periods (years) over which regeneration may develop, a program to study their development during extended periods of time will be very useful to determine their long-term survival and canopy recruitment potential.

\section{Growth curves}

Although we did not find an available growth model published for any of these Quercus, the Richard's logistic model we chose here allowed us to estimate the percentage reduction in the growth rates among the light gap and the closed canopy. The dominance of $Q$. insignis as the species with the highest growth rate in both environments (closed canopy and light gap) was evident over the 13 month study period. Among environments, the constant (Table 2) for stem growth rate of $Q$. insignis 
was reduced $41 \%$ in the closed canopy, while the growth rate constants of $Q$. sartorii and $Q$. xalapensis were reduced an average of $54 \%$. A longer period of study is required to determine if the Richard's logistic model is the best fit for these species; however, we can provide evidence that this model is a good fit for these Quercus species during their early establishment (Table 2).

\section{Conclusions}

This study indicates that seedlings of $Q$. insignis, $Q$. sartorii and Q. xalapensis have significantly lower growth and biomass production under a closed canopy (9\% light) than in a light gap. Considering this behavior, we recommend introducing these three Quercus species into light gaps or under isolated trees that act as nurse species during the establishment process. Nonetheless, they are also capable of establishing under heavy shade, particularly Q. insignis, and may be suited to enrichment planting under a canopy prior to treatments that would create gaps. The larger acorn of $Q$. insignis likely allows it to more rapidly obtain a larger size than either $Q$. sartorii or $Q$. $x a$ lapensis under high and low light conditions during the first year of its establishment. For its higher tolerance to low light levels, we consider that $Q$. insignis can be classified as an intermediate successional species, while Q. sartorii and Q. xalapensis can be classified as early successional species. Consequently, different levels of canopy opening can provide varying opportunities for establishment success of these Quercus species. Practically, this knowledge can be used by silviculturists and restoration practitioners to enhance oak regeneration in Mexican cloud forest restoration efforts.

\section{Acknowledgements}

The authors are grateful to Luis Alejandro 98
Olivares López for his help in the field experiment. Garcia De La Cruz thanks the Consejo Nacional de Ciencia y Tecnología for the doctoral scholarship (No. 272172) awarded for studies at the Centro de Investigaciones Tropicales, Universidad Veracruzana. Brent Frey acknowledges support from the USDA National Institute of Food and Agriculture, McIntire-Stennis Cooperative Forestry Research Program, and the College of Forest Resources Forest and Wildlife Research Center, and Department of Forestry at Mississippi State University. Lastly, we extend our thanks to C. Sabatia and anonymous reviewers for their helpful comments on data analysis and earlier versions of this paper.

\section{References}

Alfonso-Corrado C., Campos J.E., Mendoza A., Aguirre-Hidalgo V., Valencia-Davalos S., González-Adame G., Wooden Garvey F., Clark-Tapia R. 2014. Restoration-focused germination and development of fivee central mexican oak species. Open Journal of Forestry 4: 171-180. DOI: 10.4236/ojf.2014.43023

Álvarez-Aquino C., Williams-Linera G., Newton A.C., 2004. Experimental native tree seedlings establishment for the restoration of a Mexican cloud forest. Restoration Ecology: 12(3): 412-418. DOI: 10.1111/j.10612971.2004.00398.x

Ashton P.M.S., Berlyn C.P., 1994. A comparison of leaf physiology and anatomy of Quercus (Section Erythrobalanus-Fagaceae) species in different light environments. American Journal of Botany 81(5): 589-597. DOI: $10.2307 / 2445734$

Augspurger C.K., 1984. Light requirements of neotropical tree seedlings: a comparative study of growth and survival. Journal of Ecology 72(3): 777-795. DOI: $10.2307 / 2259531$

Bubb P., May I., Miles L., Sayer, J., 2004. Cloud forest agenda. UNEP-WCMC, Cambridge, United Kingdom, $36 \mathrm{p}$.

Castillo-Campos G., Luna V.E., 2009. Flora y vegetación del municipio de Coatepec, Veracruz. [Flora and vegetation of the municipality of Coatepec, Veracruz]. Flora de Veracruz. Instituto de Ecología, A.C., Centro de Investigaciones Tropicales, Universidad Veracruzana, México, $281 \mathrm{p}$.

Colbert, J.J., Schuckers, M. and Fekedulegn, D., 2003. Comparing models for growth and management of forest tracts. In: Amaro A., Reed D., Soares P. (eds.), Modelling forest systems, pp. 335-346. DOI: 


\subsection{9/9780851996936.0335}

Danner B.T., Knapp A.K., 2001. Carbon and water relations of juvenile Quercus species in tall-grass prairie. Journal of Vegetation Science 12(6): 807-816. DOI: $10.2307 / 3236868$

Dillaway D.N., Stringer J.W., Rieske L.K., 2007. Light availability influences root carbohydrates, and potentially vigor, in white oak advance regeneration. Forest Ecology and Management 250(3): 227-233. DOI: 10.1016/j.foreco.2007.05.019

Fenner M., Thompson K., 2005. The ecology of seeds. Cambridge University Press. DOI: 10.1017/ CBO9780511614101

Figueroa-Rangel B.L., Olvera-Vargas M., 2000. Regeneration patterns in relation to canopy species composition and site variables in mixed oak forests in the Sierra de Manantlán Biosphere Reserve, Mexico Ecological Research 15: 249-261. DOI: 10.1046/j.14401703.2000.00346.x

García M.E., 1973. Modificaciones al sistema de clasificación climática de Köppen. [Modifications to Köppen's climate classification system]. Universidad Nacional Autónoma de México, México, 146 p.

García de la Riva E., Pérez-Ramos I., Navarro Fernández C., Olmo M., Marañón M., Villar R., 2014. Rasgos funcionales en el género Quercus: estrategias adquisitivas frente a conservativas en el uso de recursos. [Functional traits in the Quercus genus: acquisitive versus conservative resource-use strategies]. Ecosistemas 23(2): 82-89. DOI: 10.7818/ECOS.2014.23-2.11

Gardiner E.S., Hodges J.D., 1998. Growth and biomass distribution of cherrybark oak (Quercus pagoda Raf.) seedlings as influenced by light availability. Forest Ecology and Management 108(1-2): 127-134. DOI: 10.1016/S0378-1127(98)00220-5

Givnish T.J., 1988. Adaptation to sun and shade: a wholeplant perspective. Australian Journal of Plant Physiology 15: 63-92. DOI: 10.1071/PP9880063

Gómez-Aparicio L., Valladares F., Zamora R., 2006. Differential light responses of Mediterranean tree saplings: linking ecophysiology with regeneration niche in four co-occurring species. Tree Physiology 26(7): 947-958. DOI: $10.1093 /$ treephys/26.7.947

González-Espinosa M., MeaveJ.A., Lorea-Hernández, F.G., Ibarra-Manríquez, G., \& Newton, A.C. 2011. The Red List of Mexican cloud forest trees. Fauna and Flora International, BGCI Plants for the Planet, Global Trees Campaign, IUCN and SSC Species Survival Commission. Cambridge, United Kingdom. 149 p.

Gribko L., Schuler T., Ford W., 2002. Biotic and abiotic mechanisms in the establishment of northern red oak seedlings: a review. USDA Forest Service. DOI: 10.2737/NE-GTR-295

Hunt R., Causton D.R., Shipley AP., Askew AP., 2002. A modern tool for classical plant growth analysis. Annals of Botany 90(4): 485-488. DOI: $10.1093 / \mathrm{aob} / \operatorname{mcf} 214$

Kitajima K., Fenner M., 2000. Ecology of seedling regeneration. Seeds: The ecology of regen- eration in plant communities, pp. 331-359. DOI: 10.1079/9780851994321.0331

Leck M.A., Outred H.A., 2008. Seedling natural history. In: Leck M. A., Parker T., Simpson R. (eds.), Seedling ecology and evolution. Cambridge, Cambridge University Press, pp. 18-41. DOI: 10.1017/ CBO9780511815133.004

López-Barrera F., Mansons R.H., González-Espinosa M., Newton A.C., 2006. Effects of the type of montane forest edge on oak seedling establishment along forest-edge-exterior gradients. Forest Ecology and Management 225: 234-244. DOI: $10.1016 /$ j.foreco.2005.12.055

Montes-Hernández B., López-Barrera F., 2013. Seedling establishment of Quercus insignis: a critically endangered oak tree species in southern Mexico. Forest Ecology and Management 310: 927-934. DOI: 10.1016/j. foreco.2013.09.044

Ortega-Pieck A., López-Barrera F., Ramírez-Marcial N., García-Franco J.G., 2011. Early seedling establishment of two tropical montane cloud forest tree species: The role of the native and exotic grasses. Forest Ecology and Management 261 (7): 1336-1343. DOI: 10.1016/j. foreco.2011.01.013

Poorte H., Nagel O., 2000. The role of biomass allocation in the growth response of plants to different levels of light, $\mathrm{CO} 2$, nutrients and water: A quantitative review. IMF Occasional Papers 27(12):1191.

Poorter L., 2001. Light-dependent changes in biomass allocation and their importance for growth of rain forest tree species. Functional Ecology 15: 113-123. DOI: 10.1046/j.1365-2435.2001.00503.x

Ramírez-Bamonde E.S., Sánchez-Velásquez L.R., Andrade-Torres A., 2005. Seedling survival and growth of three species of mountain cloud forest in Mexico, under different canopy treatments. New Forests 30(1): 95-101. DOI: 10.1007/s11056-004-5397-5

Saldaña-Acosta A., Meave J.A. Sánchez-Velásquez L.R., 2009. Seedling biomass allocation and vital rates of cloud forest tree species: Responses to light in sombra house conditions. Forest Ecology and Management 258: 1650-1659. DOI: 10.1016/j.foreco.2009.07.027

SEMARNAT., 2013. Inventario Estatal Forestal y de Suelos. [Forest and Soils State Inventory]. Veracruz de Ignacio de la Llave. Secretaría de Medio Ambiente y Recursos Naturales, México, 219 p.

Tanouchi H., 1996. Survival and growth of two coexisting evergreen oak species after germination under different light conditions. International Journal of Plant Sciences 157(4): 516-522. DOI: 10.1086/297370

Van Hees A.F.M., 1997. Growth and morphology of pedunculate oak (Quercus robur L) and beech (Fagus sylvatica $\mathrm{L}$ ) seedlings in relation to shading and drought. Annales des Sciences Forestières 54: 9-18. DOI: 10.1051/forest:19970102

Valladares F., Chico J., Aranda I., Balaguer L., Dizengremel P., Manrique E., Dreyer E., 2002. The greater seedling high-light tolerance of Quercus robur over 
Fagus sylvatica is linked to a greater physiological plasticity. Trees 16: 395-403. DOI: $10.1007 /$ s00468002-0184-4

Welander N.T., Ottonson B., 1998. The influence of shading on growth and morphology in seedlings of Quercus robur L. and Fagus sylvatica L. Forest Ecology and Management 107: 117-126. DOI: 10.1016/S03781127(97)00326-5

Williams-Linera G., 2007. El bosque de niebla del centro de Veracruz: ecología, historia, destino en tiempos de fragmentación y cambio climático. [The cloud forest of central Veracruz: ecology, history, destiny in times of fragmentation and climate change]. CONABIO-Instituto de Ecología A.C., Xalapa, Veracruz, México, 208 p. Williams-Linera G., Manson R.H., Isunza-Vera E., 2002. La fragmentación del bosque mesófilo de montaña y patrones de uso del suelo en la región oeste de Xalapa, Veracruz, México. [Fragmentation of cloud forest and land use patterns in the western region of Xalapa, Veracruz, Mexico]. Maderas y Bosques 8(1): 73-89. 